\title{
Effect of plant bio-regulators on photosynthesis, growth and yield efficiency of pear trained on Y-trellis system
}

\author{
SHUBHKIRAN KAUR, MANDEEP SINGH GILL*, P.P.S. GILL and NAV PREM SINGH \\ Department of Fruit Science, Punjab Agricultural University, Ludhiana, 141004 \\ ${ }^{*}$ Corresponding author: mandeepgill21@pau.edu
}

\begin{abstract}
'Patharnakh' and 'Punjab Beauty' are major pear cultivars grown under the subtropical conditions of northwestern India. These pear cultivars tend to put up profuse vegetative growth under the high density planting that leads to excessive shading of bearing zone of canopy. To facilitate light penetration into inner plant canopy, there is a need to contrive an efficient approach for vegetative growth management. The foliar applications of varying concentrations of plant bio-regulators viz. Prohexadione calcium (ProCa) $\left(100,200,400 \mathrm{mg} \mathrm{L}^{-1}\right)$ and Paclobutrazol (PBZ) $\left(100,250,500 \mathrm{mg} \mathrm{L}^{-1}\right)$ were done at 10 days after full bloom (DAFB) 'Patharnakh' and 'Punjab Beauty' pear plants trained on the Y-trellis training system. Shoot length, leaf area index and trunk cross-sectional areas (TCSA) were greatly reduced by Pro-Ca 200 and $400 \mathrm{mg} \mathrm{L}^{-1}$ concentrations. Treatments enhanced light penetration and photosynthesis. Fruit weight improved with plant bio-regulator treatments resulting in increased yield efficiency of pear plants. This study exhibited a strong positive correlation between light availability and yield efficiency of pear plants.
\end{abstract}

Keywords : Pear, Plant bio-regulators, photosynthesis rate, vegetative growth and yield efficiency

Low chill cultivars namely 'Patharnakh' and 'Punjab Beauty' of pear are successfully grown in Punjab state of India with productivity of $23.02 \mathrm{t} \mathrm{ha}^{-1}$ (Anonymous, 2019). In the absence of compatible dwarfing rootstock, the problem of excessive growth along with long juvenility in pear under the subtropical regions is well known. There is a need to maintain a balance between growth and fruiting. Pruning is the most prevalent technique used to improve light penetration into the inner canopy at the expense of reserved photosynthates of wood, bark and leaves. However, during growing season, excessive vegetative growth occurs apparently as a ramification of severe dormant pruning. The use of plant bio-regulators to restrict vegetative growth is one of the novel approach which could be employed along with pruning. Plant hormone gibberellin is responsible for excessive vegetative growth and productivity is also reduced due to poor light penetration within inner tree canopy (Prive et al., 2004). In high density plantations, light is one of the important ecological factors that affects the rate of photosynthesis and the quality of fruit produced. Paclobutrazol improved light penetration in inner canopies of pear (Elfving et al. 2013) and apple (Prive et al. 2004) by reducing vegetative growth. Earlier reports revealed that Paclobutrazol and Pro-Ca reduced vegetative growth and increased yield of 'Bagugosa' (Gupta and Bist, 2005) in subtropics and in 'Clapp's Favorite' pear (Lal et al., 2018) under temperate conditions. However, the effect of these plant bio-regulator applications on light penetration, the net photosynthesis rate and their influence on pear fruit yield maintained on the Y-trellis training under high density planting system is still not known. Hence, this study was intended to evaluate the potential of Pro-Ca and PBZ on vegetative growth control, penetration of photosynthetically active radiation (PAR), net photosynthesis rate, and; influence of PAR on yield efficiency of 'Patharnakh' and 'Punjab Beauty' pear cultivars grown under the subtropics of India.

\section{MATERIALS AND METHODS}

\section{Experimental details}

This study was carried out at the Fruit Research Farm of Punjab Agricultural University, Ludhiana, Punjab, situated at the latitude of $30.90^{\circ} \mathrm{N}$, longitude of $75.79^{\circ} \mathrm{E}$ and at an altitude of $244 \mathrm{~m}$ above $\mathrm{msl}$. This experiment was conducted on seven years old 'Patharnakh' and 'Punjab Beauty' pear plants grafted on Pyrus pashia rootstock and trained on the Y-trellis system at $3 \times 3 \mathrm{~m}$ spacing. The experimental site represents a semi-arid and sub-tropical climate, i.e. summers are very hot and dry, followed by wet monsoon season from 
July to September and winters are mild. The maximum air temperature often rises above $40{ }^{\circ} \mathrm{C}$ during the summer months i.e. May-June while in the winter months temperature falls down to less than $5{ }^{\circ} \mathrm{C}$ occasionally accompanied by frost spells. Average annual rainfall of this area is about 885 $\mathrm{mm}$ and approximately 75 per cent of this is received during the monsoon season.

Pear plants were treated with Regalis Plus ${ }^{\mathrm{TM}}$ (Prohexadione-Ca 10\% WG) and Cultar ${ }^{\mathrm{TM}}$ (Paclobutrazol $25 \% \mathrm{~W} / \mathrm{V})$. Treatments of plant bio-regulators included varying concentrations of Pro-Ca (100, 200 and $400 \mathrm{mg}$ $\left.\mathrm{L}^{-1}\right)$ and PBZ (100, 250 and $\left.500 \mathrm{mg} \mathrm{L}^{-1}\right)$. Foliar applications of the plants in a single treatment unit were done with powered knapsack sprayer using 5 liters of solution till the surface runoff point. The unit of control plants was sprayed with water. All the treatments were applied at 10 days after full bloom (DAFB) in the month of March. The experiment was deployed in Randomized Block Design with three replications per treatment.

After the treatments applications, measurement of PAR in the upper and lower canopies was initiated at the fortnight interval from April to July during 10-11 am using an Apogee MQ-306 line quantum sensor (6 sensors). Leaf area index (LAI) was assessed underneath the plant canopy with CI-110 Plant Canopy Imager (CID Bio Science, Inc, USA) before the harvest of fruit. Net photosynthesis rate was measured from fully expanded leaves during May to July on clear days using a portable photosynthesis system (CI-340, CID Bio Science, USA). Total leaf chlorophyll content was estimated from freshly samples leaves through spectrophotometric analysis using DMSO (dimethyl sulphoxide). Fruit number from each replicated unit was counted in the month of July. After harvesting fruit weight of a sample of twenty fruits was measured with the help of electronic weighing balance (AND EK-1200i, Co.LTD Japan). Length of 25 uniform annual pruned shoots was measured during the period of rest in the month of January. Trunk circumference of the pear plants was measured at 10 $\mathrm{cm}$ above graft union. TCSA was calculated from trunk circumference as described by Cline (2017). Yield efficiency was expressed as the ratio of yield of a plant to its TCSA as suggested by Cares et al., (2014).

Data was analyzed using one way analysis of variance (ANOVA) procedure in Software SAS 9.3 (The SAS system for Windows, Version 9.3, SAS Institute, Cary, NC). Values of all the parameters were recorded in triplicate and presented as mean \pm standard deviation. Significant results at $P \leq 0.05$ were subjected to mean comparisons through LSD test. Pearson correlation coefficients and linear regression were assessed for PAR and yield efficiency; net photosynthesis rate and fruit weight.

\section{RESULTS AND DISCUSSION}

\section{Effect of plant bio-regulators on TCSA and shoot length}

Shoot length and TCSA recorded during dormancy period were significantly reduced by all the treatments of plant bio-regulators (Fig. 1). Minimum shoot length was observed in Pro-Ca $400 \mathrm{mg} \mathrm{L}^{-1}$ treated 'Patharnakh' plants with $31.11 \%$ reduction in length as compared to the control. Similarly, lowest shoot length values were observed in ProCa 200, 400 and PBZ $500 \mathrm{mg} \mathrm{L}^{-1}$ treated 'Punjab Beauty' plants which were $\sim 16 \%$ shorter as compared to the shoots of control plants. Previous research findings have also proved the ability of growth reduction by PBZ and Pro-Ca in pear plants (Asin and Vilardell, 2006). Percent reduction in shoot length of 'Patharnakh' pear was greater than 'Punjab Beauty' might be due to their difference in growth pattern and vigour. Vegetative growth controlling effect of Pro-Ca had also been observed by Costa et al. (2004) in apple trees. As compared to control, all the treatments reduced TCSA and Pro-Ca $400 \mathrm{mg} \mathrm{L}^{-1}$ resulted in reduction of $\sim 8.53 \%$ in 'Patharnakh' and; $8.63 \%$ in 'Punjab Beauty' pear plants. In accordance with our results, decrease in TCSA by PBZ sprays in peach plants has also been reported (Arzani et al., 2009). Decrement of TSCA with Pro-Ca was explained as the result of the reduction in competition between vegetative and reproductive growth after the respective treatment by Duyvelshoff and Cline (2013) which ultimately resulted in higher yield.

\section{Effect of plant bio-regulators on leaf area index (LAI)}

LAI was observed $41.72 \%$ lower than the control in PBZ $500 \mathrm{mg} \mathrm{L}^{-1}$ treated plants of 'Patharnakh' and in 'Punjab Beauty' it was reduced up to $\sim 31 \%$ by Pro-Ca $200,400 \mathrm{mg}$ $\mathrm{L}^{-1}$ and PBZ $500 \mathrm{mg} \mathrm{L}^{-1}$ treatments (Fig. 1). Present findings showed that applications of PBZ and Pro-Ca lowered the value of leaf area index which is a ratio of canopy leaf area per unit ground surface area and is similar to the findings by Glenn and Miller (2005) in apple trees.

\section{Effect of plant bio-regulators on total leaf chlorophyll content}

The total leaf chlorophyll content determined from leaves of 'Patharnakh' and 'Punjab Beauty' pear was recorded highest under Pro-Ca $400 \mathrm{mg} \mathrm{L}^{-1}$ treatment which was closely followed by Pro-Ca $200 \mathrm{mg} \mathrm{L}^{-1}$ treatment (Fig. 

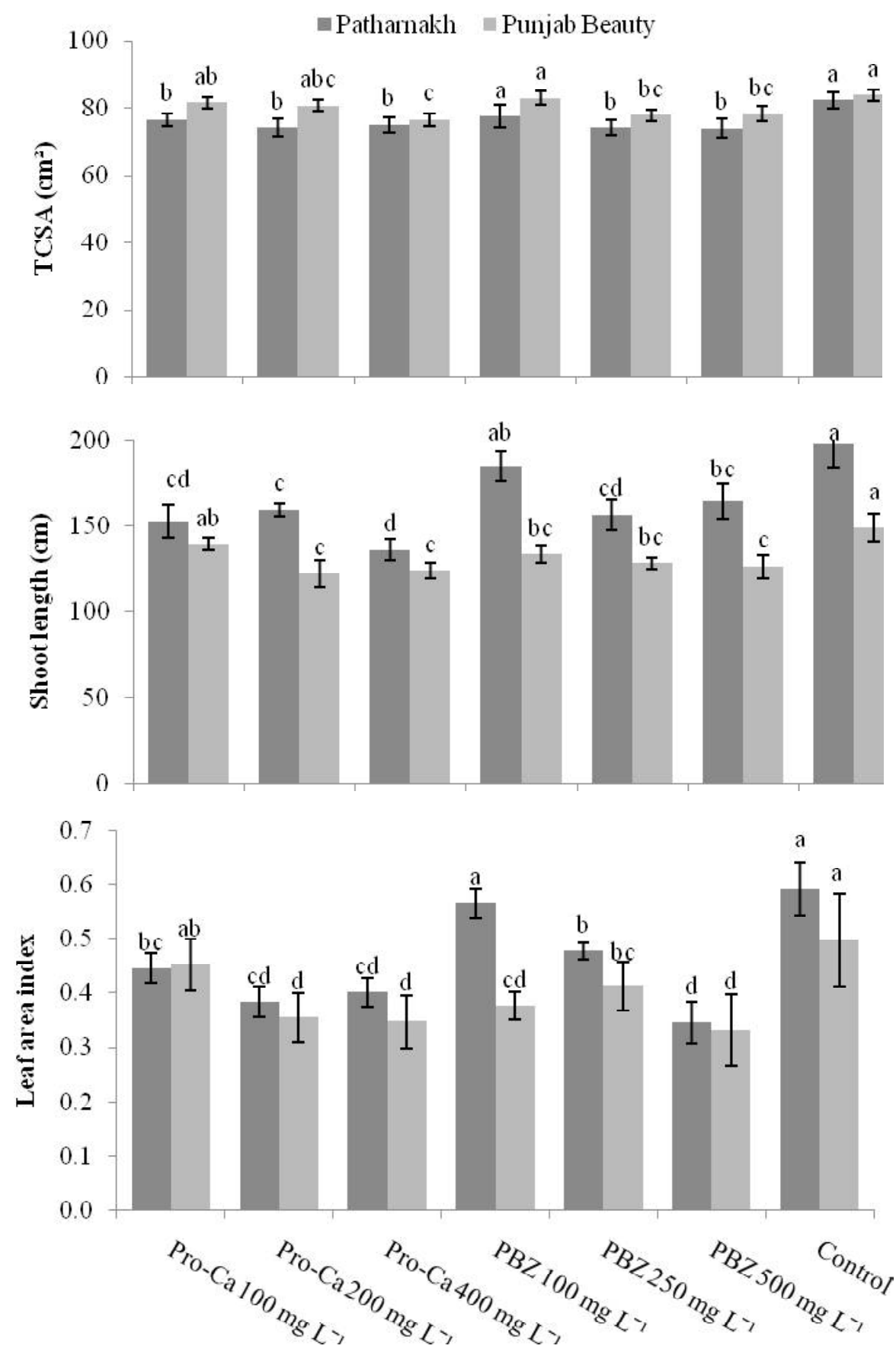

Fig.1: Effect of plant bio-regulators on the TCSA, shoot length and leaf area index of 'Patharnakh' and 'Punjab Beauty'pear. Alphabetical letters denote significant differences of mean at $\mathrm{P} \leq 0.05$ using LSD test. Values are mean \pm standard deviation.

3). In agreement to our results, Pro-Ca treatment increased leaf chlorophyll content in apple (Medjdoub et al., 2007) and the minimum was recorded in control leaves.

\section{Effect of plant bio-regulators on seasonal variation in PAR penetration}

The seasonal variation in PAR penetration through the upper and lower canopies of 'Patharnakh' and 'Punjab Beauty' pears treated with plant bio-regulators is represented in Fig. 2 (A, B, C and D). A drop in penetration of PAR irrespective of treatment was recorded throughout the season which could be attributed to an increase in foliage density with the progress of vegetative growth. In the upper canopy of 'Patharnakh' plants, significant higher penetrated 


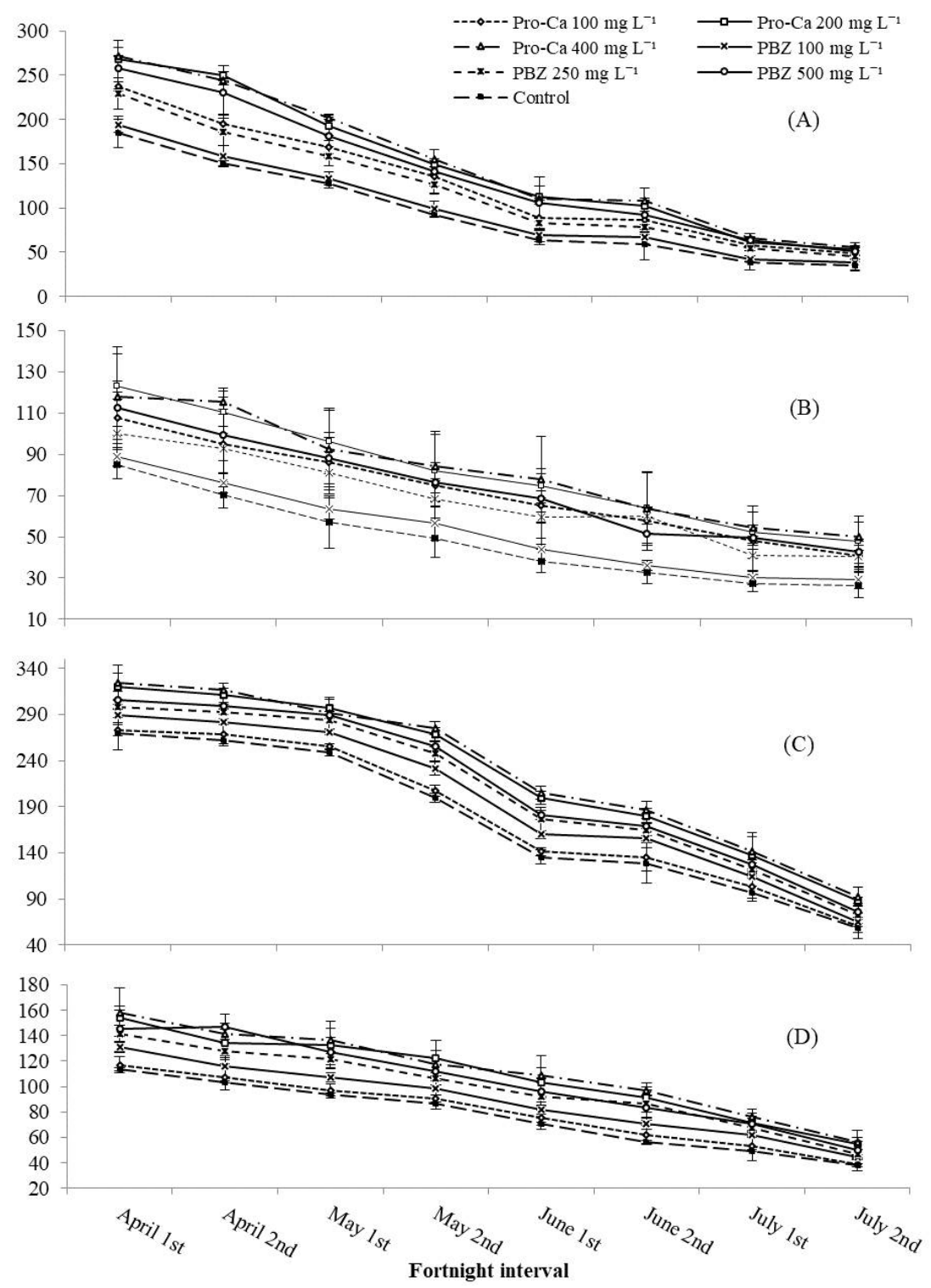

Fig.2: Effect of plant bio-regulators applications on seasonal variation in PAR penetration in 'Patharnakh' (upper-A; and lower-B) and 'Punjab Beauty' (upper-C; and lower-D) canopies. Vertical bars represent the standard deviation.

PAR was recorded under all the treatments. The PAR penetration was $47.17 \%, 57.88 \%, 66.91 \%, 82.61 \%$ and $58.3 \%$ higher in Pro-Ca $400 \mathrm{mg} \mathrm{L}^{-1}$ treated plants as compared to control plants during the $\mathrm{I}^{\text {st }}$ fortnight of April, $\mathrm{I}^{\text {st }}$ and $\mathrm{II}^{\text {nd }}$ fortnight of May; and $\mathrm{II}^{\text {nd }}$ fortnight of June and July, respectively. PAR penetration was increased by 73.96 $\%$ during $\mathrm{I}^{\mathrm{st}}$ fortnight of July with PBZ $500 \mathrm{mg} \mathrm{L}^{-1}$ treatment over the control. In lower canopy of 'Patharnakh', penetrated PAR values in treated plants were significantly higher under Pro-Ca $400 \mathrm{mg} \mathrm{L}^{-1}$ treatment during $\mathrm{II}^{\text {nd }}$ fortnight of April $(64.74 \%)$ and; $I^{\text {st }}$ fortnight of June $(103.3 \%)$ and July (97.96\%). Likewise in 'Punjab Beauty' pear, the penetration of PAR through upper canopies during all the months was significantly increased by all the treatments, except, during

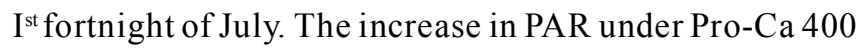
$\mathrm{mg} \mathrm{L}^{-1}$ treatment was $20.45 \%, 21.2 \%, 37.68 \%, 51.52 \%$, $44.79 \%, 45.58 \%$ and $58.46 \%$ more than the control throughout the season, except in $\mathrm{I}^{\text {st }}$ fortnight of May, where $19.77 \%$ increase was observed under Pro-Ca $200 \mathrm{mg} \mathrm{L}^{-1}$ treatment. Similarly, in lower canopy, PAR values were significantly higher in Pro-Ca $400 \mathrm{mg} \mathrm{L}^{-1}$ treated plants during $\mathrm{I}^{\text {st }}$ fortnight of April (39.25\%), $\mathrm{I}^{\text {st }}$ fortnight of May (45.52\%), first (53.58 \%) and $\mathrm{II}^{\text {nd }}$ fortnight of June (71.9\%) and It fortnight of July (54.89\%) while PBZ $500 \mathrm{mg} \mathrm{L}^{-1}$ 

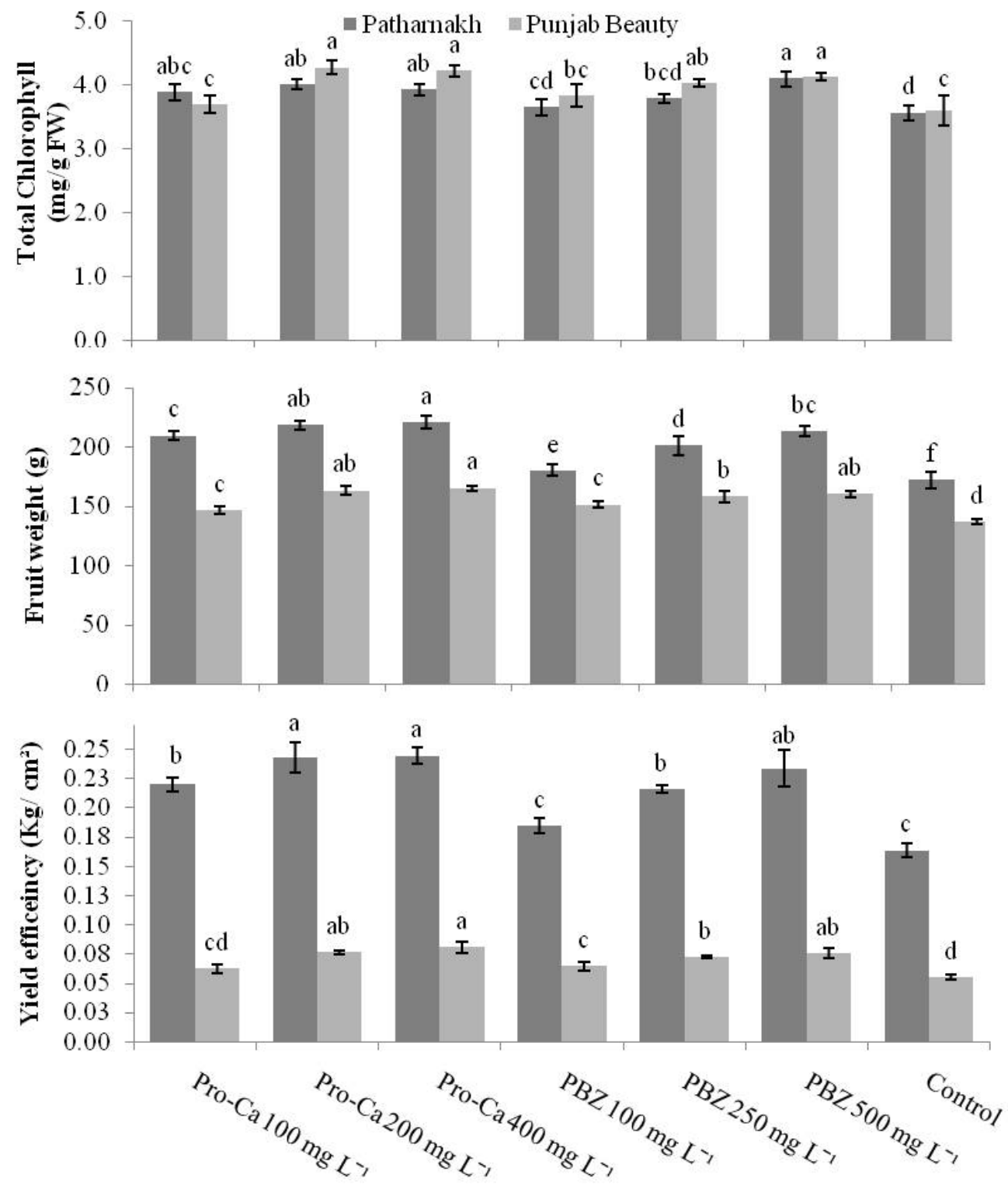

Fig.3: Effect of plant bio-regulators on the total leaf chlorophyll content, fruit weight and yield efficiency of 'Patharnakh' and 'Punjab Beauty' pear. Alphabetical letters denote significant difference of mean at $\mathrm{P} \leq 0.05$ using LSD test. Values are mean \pm standard deviation

increased PAR by $42.03 \%$ in the II ${ }^{\text {nd }}$ fortnight of April. The percent increase in penetrated PAR in the upper canopies of treated plants of both the cultivars was lower in comparison to lower canopies. Light penetration is dependent on the canopy structure and planting density. In subtropics, pear canopies develop rapidly from April to July during active fruit growth period thus, making canopies denser and declining light penetration through them throughout the season. In accordance with our results, Elfving et al. (2003) and Prive et al. (2004) reported that PBZ and Pro-Ca improved light penetration and distribution in inner canopies of pear and apple, respectively. Upper canopies received minimum of $\sim 21 \%$ increase while lower canopies received maximum of $\sim 103 \%$ increase in penetrated PAR over the control. Prive et al. (2004) also described that the impact of Pro-Ca on light interception in upper canopies was not prominent due to less shading from shoots and leaves. PAR values in 'Royal Gala' apple trees were increased due to decrease in leafarea (Medjdoub et al., 2007). Similarly, Gill et al. (2011) reported decrease in light penetration with increasing height of 'Patharnakh' pear plants. 

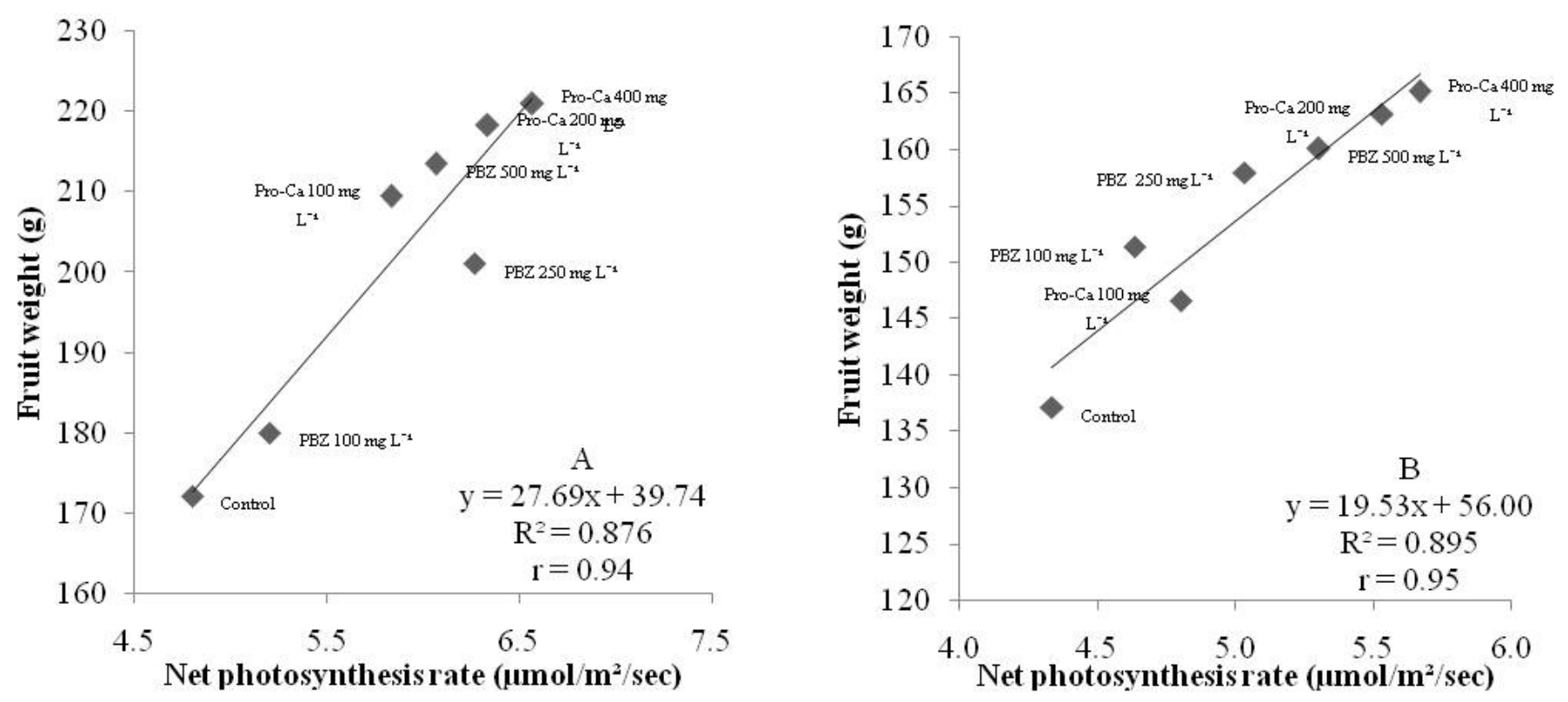

Fig.4: Relationship of net photosynthesis rate and fruit weight of 'Patharnakh' (A) and 'Punjab Beauty' (B) pear plants treated with plant bio-regulators.
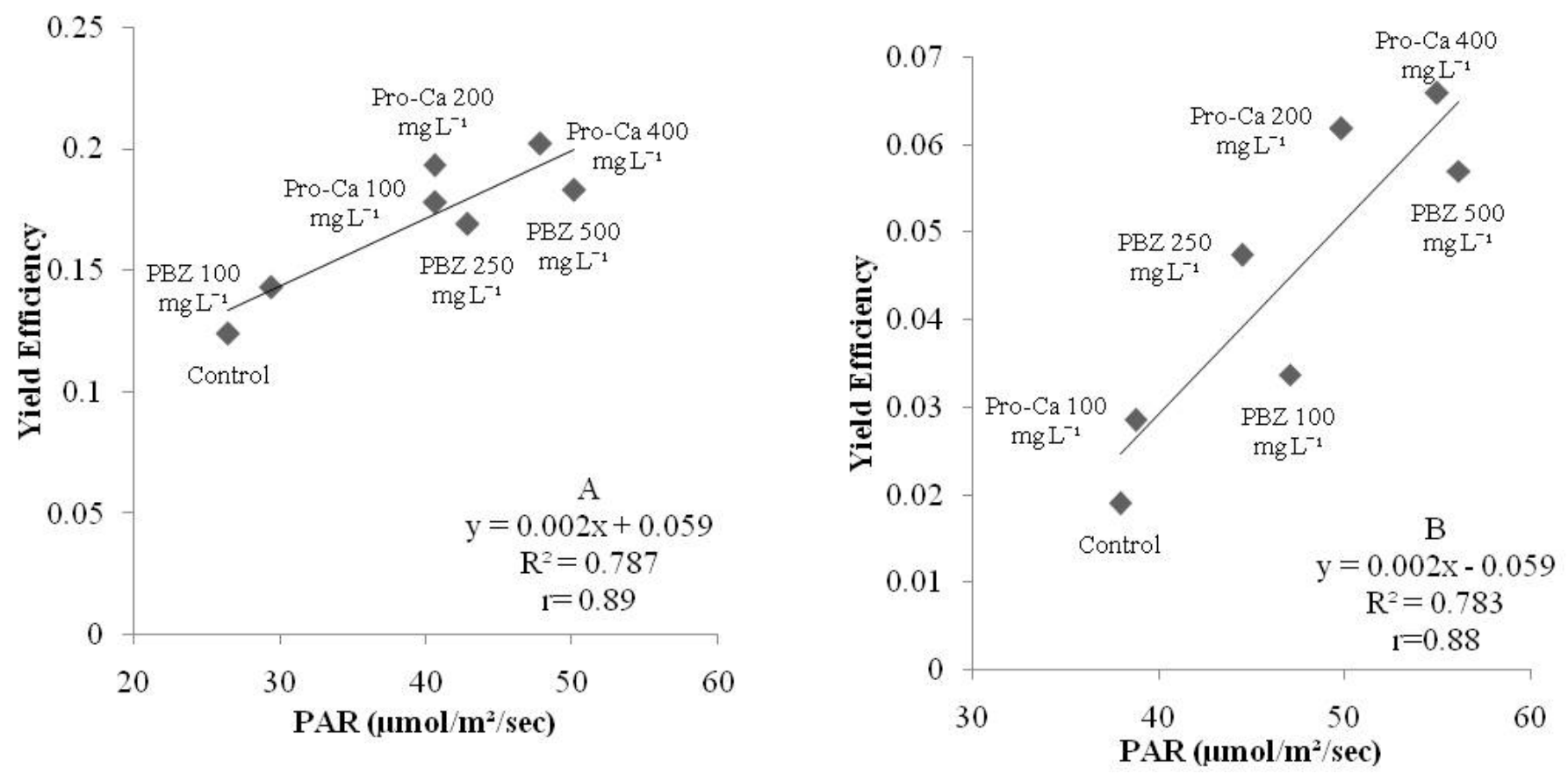

Fig.5: Relationship between PAR and yield efficiency of 'Patharnakh'(A) and 'Punjab Beauty' (B) pear plants treated with plant bio-regulators.

\section{Effect of plant bio-regulators on net photosynthesis rate}

The net photosynthesis rate of 'Patharnakh' and 'Punjab Beauty' pear leaves increased from May to June months and followed by a decline in July month. Various plant regulators treatments significantly affected the photosynthesis rate in May, June and July months but no effect was noted in 'Punjab Beauty' pear during June month (Table 1). The highest net photosynthesis rate was recorded under Pro-Ca $400 \mathrm{mg} \mathrm{L}^{-1}$ treatment followed by Pro-Ca 200 $\mathrm{mg} \mathrm{L}^{-1}$ treatment. As compared to control, Pro-Ca $400 \mathrm{mg}$ $\mathrm{L}^{-1}$ increased the net photosynthesis rate by $45.84 \%, 30.76$ $\%$ and $36.87 \%$ during May, June and July, respectively in 'Patharnakh' and by $23.94 \%, 21.21 \%$ and $30.95 \%$, respectively in 'Punjab Beauty'. The minimum photosynthesis rate was recorded in control plants during all the months. The increase in photosynthesis rate in growth regulator treatments might be ascribed to reduction in 
Table 1: Effect of plant bio-regulators on the net photosynthesis rate of 'Patharnakh' and 'Punjab Beauty' pear.

\begin{tabular}{|c|c|c|c|c|c|c|}
\hline \multirow[t]{2}{*}{ Treatment } & \multicolumn{2}{|c|}{ May } & \multicolumn{2}{|c|}{ June } & \multicolumn{2}{|c|}{ July } \\
\hline & Patharnakh & $\overline{\text { Punjab Beauty }}$ & Patharnakh & $\overline{\text { Punjab Beauty }}$ & Patharnakh & Punjab Beauty \\
\hline Pro-Ca 100 mg LÉ ${ }^{1}$ & $6.93^{\mathrm{ab}}$ & $5.63^{\mathrm{cd}}$ & $8.07^{\mathrm{ab}}$ & $6.43^{\mathrm{a}}$ & $5.83^{\mathrm{ab}}$ & $4.63^{\text {cd }}$ \\
\hline Pro-Ca 200 mg LÉ ${ }^{1}$ & $7.40^{\mathrm{ab}}$ & $6.47^{\mathrm{ab}}$ & $8.47^{\mathrm{ab}}$ & $7.53^{\mathrm{a}}$ & $6.33^{\mathrm{a}}$ & $5.53^{\mathrm{ab}}$ \\
\hline Pro-Ca 400 mg LÉ 1 & $7.73^{\mathrm{a}}$ & $6.73^{\mathrm{a}}$ & $8.67^{\mathrm{a}}$ & $7.60^{\mathrm{a}}$ & $6.57^{\mathrm{a}}$ & $5.67^{\mathrm{a}}$ \\
\hline PBZ 100 mg LÉ ${ }^{1}$ & $5.83^{\mathrm{cd}}$ & $5.93^{\mathrm{bcd}}$ & $6.97^{\mathrm{c}}$ & $6.70^{\mathrm{a}}$ & $5.20^{\mathrm{bc}}$ & $4.80^{\mathrm{bcd}}$ \\
\hline PBZ 250 mg LÉ ${ }^{1}$ & $6.63^{\mathrm{bc}}$ & $6.17^{\mathrm{abc}}$ & $7.87^{\mathrm{b}}$ & $7.03^{\mathrm{a}}$ & $6.27^{\mathrm{a}}$ & $5.03^{\mathrm{abcd}}$ \\
\hline PBZ 500 mg LÉ ${ }^{1}$ & $7.17^{\mathrm{ab}}$ & $6.33^{\mathrm{abc}}$ & $8.17^{\mathrm{ab}}$ & $7.30^{\mathrm{a}}$ & $6.07^{\mathrm{a}}$ & $5.30^{\mathrm{abc}}$ \\
\hline Control & $5.30^{\mathrm{d}}$ & $5.43^{\mathrm{d}}$ & $6.63^{c}$ & $6.27^{\mathrm{a}}$ & $4.80^{\mathrm{c}}$ & $4.33^{\mathrm{d}}$ \\
\hline
\end{tabular}

Alphabetical letters denote significant difference of mean at $\mathrm{P} \leq 0.05$ using LSD test.

vegetative growth by these treatments which facilitated better light penetration in the canopy of plants. In apple trees, Medjdoub et al. (2007) also described that Pro-Ca resulted in higher light penetration and chlorophyll concentration which resulted in overall improvement in photosynthesis.

\section{Effect of plant bio-regulators on fruit weight and yield efficiency}

Fruits harvested from all the bio-regulator treated plants were significantly larger than untreated plants (Fig 3). The maximum weight was obtained from Pro-Ca $400 \mathrm{mg}$ $\mathrm{L}^{-1}$ treated pear plants and it was increased by $28.34 \%$ and $20.42 \%$ over control in 'Patharnakh' and 'Punjab Beauty' pear, respectively. Brar et al. (2011) reported that guava plants with more depth in canopy had lowest fruit size and weight. The increase in fruit weight of Regalis ${ }^{\mathrm{TM}}$ treated pear was due to reduced competition between growing fruits and vegetative parts (Asin et al., 2005). Kundu et al. (2013) also obtained larger fruits with high productivity in PBZ treated 'Gola' pear. The present results also showed that net photosynthesis rate was highly correlated to fruit weight with a significant linear effect (Fig. 4 A and B) indicating increased production and distribution of photosynthates to fruits. Yield efficiency is the relative estimation of yield obtained per unit $\mathrm{cm}^{2}$ of TCSA and positively related to light penetrated in pear canopies (Fig.6). It was obtained highest under Pro-Ca 200 and $400 \mathrm{mg} \mathrm{L}^{-1}$ treatments in 'Patharnakh' while in 'Punjab Beauty' highest yield efficiency was observed under Pro- $400 \mathrm{mg} \mathrm{L}^{-1}$ (Fig. 3). Agha and Buckley (1986) also observed an increase in apple production due to increase in light interception following growth retardant application and in accordance to our assessment of significant correlation and regression between PAR and yield efficiency (Fig. 5 A and B). Arzani and Roosta (2004) explained the reduction in TCSA to be beneficial and inversely related to crop density and yield efficiency.

\section{CONCLUSIONS}

Overall, this study has revealed that Pro-Ca $400 \mathrm{mg}$ $\mathrm{L}^{-1}$ was the most effective in restricting vegetative growth, improving the availability of light in the plant canopy and fruit production of pear plants

\section{ACKNOWLEDGEMENT}

The research support by the Punjab Agricultural University, Ludhiana, Punjab is duly acknowledged.

\section{REFERENCES}

Anonymous. (2019). Area and production of different fruits in Punjab state. Directorate of Horticulture, Punjab, Chandigarh (www.punjabhorticulture.com).

Asin, L., Dalmau, R., Bonany, J., Pages, J.M. and Vilardell, P. (2005). Effect of prohexadione-Ca on growth regulation, yield, fruit set and return bloom, in 'Blanquilla' and 'Conference', the two main pear cultivars grown in Spain. Acta Hortic., 671:525-32.

Agha, N.S.A. and Buckley, W.R. (1986). Assessment of canopy efficiencyof apple trees in beds. I. Canopy development assessed by direct light measurements. J. Hortic. Sci., 61:153-59.

Arzani, K., Bahadori, F. and Piri, S. (2009). Paclobutrazol reduces vegetative growth and enhances flowering and fruiting of mature 'JHHale' and 'Red Skin' peach trees. Hortic. Environ. Biotech., 50:84-93. 
Asin, L. and Vilardell, P. (2006). Effect of paclobutrazol and prohexadione-Ca on shoot growth rate and growth control in 'Blanquilla' and 'Conference' pear. Acta Hortic., 727:133-38.

Arzani, K., Bahadori, F. and Piri, S. (2009). Paclobutrazol reduces vegetative growth and enhances flowering and fruiting of mature 'JHHale' and 'Red Skin' peach trees. Hortic. Environ. Biotech., 50:84-93.

Arzani, K. and Roosta, H.R. (2004). Effects of paclobutrazol on vegetative and reproductive growth and leaf mineral content of mature apricot (Prunus armeniaca L.) trees. J. Agr. Sci. Technol., 6: 43-55.

Brar, J.S., Singh, S.P. and Bal, J.S. (2011). Physico-chemical properties of guava fruits as influenced by solar radiation penetration in plants canopies. J. Agrometeorol., 13:5053.

Cares, J., Sagredo, K.X. and Cooper, T. (2014). Effect of prohexadione calcium on vegetative and reproductive development in sweet cherry trees. Acta Hortic., 1058: 357-64.

Cline, J.A. (2017). Prohexadione-Ca and ethephon suppress shoot growth of sweet cherry [Prunus avium (L.) L.]. Can. J. Plant. Sci., 97: 601-09.

Costa, G., Sabatini, E., Spinelli, F.,Andreotti,C., Bomben, C. and Vizzoto, G. (2004). Two years of application of prohexadione-Ca on apple: effect on vegetative and cropping performance, fruit quality, return bloom and residual effect. Acta Hortic., 653: 35-40.

Duyvelshoff, C. and Cline, J.A. (2013). Ethephon and prohexadione-calcium influence the flowering, early yield and vegetative growth of young 'Northern Spy' apple trees. Sci. Hortic., 151: 128-34.
Elfving, D.C., Lombardini, L., McFerson, J.R., Dreake, S.R., Faubion, D.F., Auvil, T.D., Ee, G.V. and Visser, D.B. (2003). Effects of directed applications of prohexadionecalcium to tops of mature pear trees on shoot growth, light penetration, pruning and fruit quality. J. Am. Pomol. Soc., 57: 45-57.

Gill, P.P.S., Dhillon, W.S., Singh, N.P. and Singh, S. (2011). The influence of canopy architecture on light penetration, soil temperature and fruiting in sub-tropical pear. $J$. Agrometeorol., 13: 157-59.

Glenn, D.M. and Miller, S.S. (2005). Effects of apogee on growth and whole-canopy photosynthesis in spur 'Delicious' apple trees. Hort Science., 40 : 397-400.

Gupta, N.K. and Bist, L.D. (2005). Effect of different planting systems and paclobutrazol on vegetative growth of Bagugosa pear. Indian J. Horti., 62: 20-3.

Kundu, M., Joshi, R., Rai, P.N. and Bist, L.D. (2013). Effect of plant bio-regulators on fruit growth, quality and productivity of pear cv. Gola under tarai condition. $J$. Appl. Horti., 15:106-09.

Lal, M., Mir, M.M., Iqbal, U. and Kumar, A. (2018). Response of prohexadione calcium and paclobutrazol on growth and physio-chemical characteristics of pear cv. Clapp's Favorite. Indian J. Horti., 75:191-96.

Medjdoub, R., Val, J. and Blanco, A.(2007). Physiological effects of prohexadione-calcium in apple trees:effects on parameters related to photoproductivity. J. Hort. Sci. Biotechnol.,82: 126-32.

Prive, J.P., Fava, E., Cline, J. and Byl, M. (2004). Preliminary results on the efficacy of apple trees treated with the growth retardant prohexadione-calcium (Apogee $\AA$ ) in Eastern Canada. Acta Hortic., 636:137-44. 